\title{
THE AMICUS CURIAE BRIEF: FROM FRIENDSHIP TO ADVOCACY
}

\author{
SAMUEL KRISLOV†
}

THE pretense by the lawyer that all precedents are, in Holmes' phrase, "born free and equal" all too often produces a curious portrait of a static legal universe where instruments and decisions alike avoid both decay and development. Yet, scholars ${ }^{1}$ have demonstrated many times over that imaginative utilization of the historical approach can produce insights which have been concealed by a fallacious assumption of homogeneity.

One device that, when not altogether ignored, has been thought of primarily in this antihistorical vein is the amicus curiae brief. Its delusive innocuotusness, its seemingly static function and terminology, taken together with the offhand manner of its usual use in court, have in combination forestalled intensive scholarly study. Inasmuch as the device was apparently known in Roman law ${ }^{2}$ and was an early instrument of the common law, the assumption has been that it has remained functionally unchanged as long as the term has remained constant.

Yet, the Supreme Court's first promulgation of a written rule on the subject of such briefs in 1937 followed by two modifications of this newly codified provision within a span of twenty years belies the assumption of permanence. Quietly but unmistakably, such change demonstrates the transition that has occurred and continues to occur in the use of the brief.

\section{The Amicus Curiae at Common Law}

The early use of the device is still preserved in the standard definitions, and may be found today in such sources as Corpus Juris Secundum. As Abbott's Dictionary of Terms and Phrases describes it, the amicus curiae is:

A friend of the court. A term applied to a bystander, who without having an interest in the cause, of his own knowledge makes suggestion on a point of law or of fact for the information of the presiding judge.

$\dagger$ Associate Professor, Department of Political Science, Michigan State University. The author wishes to acknowledge the assistance of the Michigan State All-University Rcsearch Fund, and the granting of released time for the undertaking of the project of which this is a part. Portions of this article will appear in Festschrift in honor of A. T. Mason (Dietze ed.).

1. For a discussion of lawyers' history, see the entertaining pages in TwIss, LAwYens AND THE CoNstitution 104-47 (1942). For a brilliant use of the genetic method, sec McIlwain, Some Illustrations of the Influence of Unchanged Names for Changing Institutions, in INterpretations of Modern Legal Philosophies 484 (Sayre cd. 1947).

2. See I Bouvier's Law Dictionary 188 (Rawle's 3d ed. 1914) (under definition of "amicus curiae").

3. See Harper \& Etherington, Lobbyists Before the Cotirt, 101 U. PA. L. REv. 1172 (1953), probably the path-finding article on this topic, and Wiener, The Suprome Court's New Rules, 68 HARv. L. REv. 20 (1954). 
Holthouse's Law Dictionary, of older vintage, puts it in even more stately fashion:

When a judge is doubtful or mistaken in matter of law, a bystander may inform the court thereof as amicus curiac. Counsel in court frequently act in this capacity when they happen to be in possession of a case which the judge has not seen or does not at the moment remember.

The function of the amicus curiae at common law was one of oral "Shepardizing," the bringing up of cases not known to the judge. The Ycarbooks cite many instances of such aid by bystanders, who not only acted on behalf of infants, but also called attention to manifest error, to the death of a party to the proceeding, and to existing appropriate statutes. ${ }^{4}$ Occasionally, however, other information was adduced. In one extreme instance, Sir George Treby, a member of Parliament, informed the court that he had been present at the passage of the statute whose meaning was contested and, as amicus curiae, wished to inform the court of the intent of Parliament in passing the legislation.5 The amicus did not even have to be an attorney to intervene, and the general attitude of the courts was to welcome such aid, since "it is for the honor of a court of justice to avoid error."'

Inasmuch as permission to participate as a friend of the court has always been a matter of grace rather than right, the courts have from the beginning avoided precise definition of the perimeters and attendant circumstances involving possible utilization of the device. This, of course, increases judicial discretion, while it concomitantly maximizes the flexibility of the device. As one court opinion has quite pointedly stated:

If such appearance was as amicus curiae and as a matter of grace, then that grace alone concerns us. Grace doth not abound through consent of one's adversary. It droppeth, withal, like mercy $\longrightarrow$ as the gentle and refreshing dews of Heaven. ${ }^{7}$

A nineteenth century decision illustrates in cxtremis the flexibility of such participation. In Ex parte Lloyd, 8 the reporter of the case, a practicing attorney, had further demonstrated his versatility by accepting retainers from both

4. The Protector v. Geering, 145 Eng. Rep. 394 (1656) (manifest error); Falmouth v. Strode, 11 Mod. 137, 88 Eng. Rep. 949 (Q.B. 1707) (information as to death of a party); Beard v. Travers, 1 Vesey Sen. 313, 27 Eng. Rep. 1052 (Ch. 1749) (participation on behalf of infants) ; and The Prince's Case, 8 Coke 1, 29a, 77 Eng. Rep. 481,516 (1606) (calling attention to a statute). The latter case is distinguished for its denouement, with the Court assailing John and Warwick Hele, the amici curiae:

But in truth the serjeant and his son have not performed the office of a good friend or of a good informer, for they have omitted one clause in the same Act ... and have thereby endeavored to deceive the Court. ...

8 Coke at 29a, 77 Eng. Rep. at 516.

5. Horton \& Ruesby, Comb. 33, 90 Eng. Rep. 326 (K.B. 1686).

6. The Protector v. Geering, 145 Eng. Rep. 394 (Ex. 1656). However, the often-repeated statement that a statute of Henry IV recognizes such a right is held by most competent authorities to be an error. See Note, Amici Curriae, 34 HARv. L. Rev. 773 n.5 (1921).

7. Ex parte Brockman, 233 Mo. 135, 154, 134 S.W. 977, 982 (1911).

8. Reported in Ex parte Elysee, Monte 69, 70 n.a (Ch. 1830). 
sides, and thus felt himself in a quandary. The Lord Chancellor, sitting in a bankruptcy case, felt he had no authority to advise an attorney as to which client to represent; but the Lord Chancellor was not to be outclone in this game of shifting roles. He promptly appointed himself amicus curiae and in this second capacity did advise the attorney. ${ }^{\circ}$ In short, through lack of precise rules the English courts developed a highly adaptable instrument for dealing with many of the problems that arise in adversary proceedings.

Perhaps the most significant enlargement of the amicus curite function was itself a partial solution to one of the most serious and enduring shortcomings of the adversary system. The problem of representation of third parties in a common law suit (and, for that matter, in equity proceedings in class suits wherc large numbers are involved) is one that does not permit either a quick or easy solution. On the contrary, the difficulties have persisted through the centuries, and devices designed to mitigate rather than cure have been the rule.

Common law procedures were peculiarly resistant to the expansion of the scope of participation by third parties in trials. The theory of trial by duel ${ }^{10}$ precludes a generous view of the right to infervene. "The fundamental principle underlying legal procedure," a court has observed, "is that parties to a controversy shall have the right to litigate the same, free from the interference of strangers."11 The proposition that the common law knew no intervenors as parties-a proposition regularly advanced by the courts-may be too sweeping; but if there were exceptions, they were in fringe areas, paralleling equity cases, as in proceeding involving heirs. ${ }^{12}$

The amicus curiae, however, was apparently utilized at an early date to avert one type of injustice which might otherwise have resulted from strict applicntion of the principles of adversary proceedings-namely, to call attention to collusive suits. The friend of the court could point out either that the proceeding was fraudulent or that it threatened to foreclose the rights of third parties through collusion. For example, in Coxe v. Phillips, ${ }^{13}$ a 1736 case, the action was on a promissory note. But the suit was collusive, allowing Mrs. Phillips to cmbarrass one Muilman, whose marriage to her had been declared null upon discovery that she had a living husband. Muilman had then proceeded to marry another woman, to the apparent irritation of Mrs. Phillips. She pleaded her marriage to Muilman, and her resulting incapacity to contract as a defense. FIad

9. Ibid. The Reporter so records his own perplexity and its resolution.

10. See Frant, Courts on Trial 80-102 (1950).

11. Consolidated Liquor Corp. v. Scotello \& Nizzi, 21 N.M. 485, 494-95, 155 Pac. 1089, 1093 (1916).

12. Berger, Intervention by Public Agencies in Prizate Litigation in the Federal Cour/s, 50 Y ALE L.J. 65 (1940). But see Rogers, Intervention at Common Law, 57 L.Q. Rev. 400 (1941). See comments indicating reluctance to permit government participation as late as 1906, in Brooks v. Southern Pac. Co., 148 Fed. 986, 987 (W.D. Ky. 1906).

13. 95 Eng. Rep. 152 (K.B. 1736).

Earlier a court held that "if an indictment be apparently vitious [be the crime what it will] it ought to be quash'd ... and therefore as amicus Curiae anyone may move to quash it." Rex v. Vaux, 90 Eng. Rep. 314 (1686). 
this defense been sustained, Muilman's marital status would have been impugned. Although he was not a party to the suit, Muilman was permitted to have his interests represented by an amicus curiae. The amicus proved successful, not only in having the action vacated, but also in having both Coxe and Phillips found in contempt of court. It is important to note that in spite of the pretense that the duty of the amicus was solely to protect and inform the court, the amicus in Coxe was permitted to stray from this exclusive obligation and defend the interests of one not a party to the law suit. One may cite precedent without participating basically for one interest or the other ; one is unlikely to call "fraud" to the attention of the court without basically taking sides. The incorporation of this new function presaged a fundamental transformation in the role of the amicus curiae-one through which the device would assume radically new dimensions. While the courts continued to cling to the proposition that the amicus was a detached servant of the court-" "he acts for no one, but simply seeks to give information to the court"14 - his services no longer precluded commitment to a cause. Indeed, the very notion of his acting for no one was belied by his rising to do just the opposite-in many instances to act directly and officially as counsel for one not formally a party to the case.

Thus, even in its native habitat, the amicus curiae brief early undervent changes that ultimately were to have profound repercussions. A step had been taken toward change from neutral friendship to positive advocacy and partisanship.

\section{The Amicus Curiae in the United States-The Shift frox Neutrality to Advocacy}

The problems of representation of third party interests under the common law system were; if anything, exacerbated by the American system. The creation of a complex federal system meant not only that state and national interests were potentially in conflict, but also that an even greater number of conflicting public interests were potentially unrepresented in the course of private suits. Legal doctrines espoused by the Supreme Court also multiplied these problems. The assertion of judicial review and of the Court's role as "umpire to the federal system" meant that disputes taking the form of litigation between private citizens were in many instances to shape the constitutional contours of the federal system.

While the number of potentially unrepresented interests was greater under a federal system, the possibility of their being heard in federal court was less. The first indication that the Supreme Court would strictly scrutinize the right of parties to appear before federal courts as parties in interest appeared in 1806 , in Strawbridge v. Curtiss. ${ }^{15}$ In finding no right to sue in federal courts against joined defendants, only one of whom possessed the requisite diversity of citizenship, Chief Justice Marshall insisted that "each distinct interest should be represented by persons, all of whom are entitled to sue or may be sued in

14. Campbell v. Swasey, 12 Ind. 70, 72 (1859).

15. 7 U.S. (3 Cranch.) 267 (1806). 
the federal courts."16 Although this ruling has not escaped criticism, ${ }^{17}$ it rew mains potent not only as originally applied but also as applied to those who seek to enter the litigation as intervenors.

If this rule excluded some parties from direct participation in federal court litigation, continuation of the common law history of hostility to intervenors worked at least an equal limitation on the availability of the federal courts to interests which were not so self-evident and formally litigious but which might, in significance and pragmatic political consequences, dwarf the narrowly defined legal issues presented by the litigants. Thus, major constitutional decisions on federal matters have seen the United States government participate, at least nominally, only as a subsidiary or remote party to the dispute. For instance, an expeditious route to a decision on the validity of a tax provision has been for a stockholder or other interested party to seek to prevent payment of the contested tax by a corporation or partnership. ${ }^{18}$ Such ventures are, at lenst in some sense, evasions of the spirit of the "real interest" rule; but they have the further fillip of relegating the taxing authority to the status of a stranger to a proceeding testing the validity of its own revenue measures.

These problems did not go unnoticed, ${ }^{19}$ nor were they left uncompensated. The Court, while contracting jurisdiction in one direction, ${ }^{20}$ established loose categories by which third party governmental authority might be vindicated. The scope of participation in cases was expanded as early as the decision in The Schooner Exchange v. McFadden. ${ }^{21}$ In that case the United States Attorney General was allowed to intervene by way of "a suggestion" in an admiralty suit. Such participation in admiralty actions and in proceedings in rem became quite common.

It originally was felt that such exceptions were compelled by the pectliar nature of in rem proceedings which, because they established rights of owncrship against the world, required full participation by all who might be adversely affected. ${ }^{22}$ As time went on it began to be realized that such equitable considerations were not unique to in rem proceedings. Rather, it was recognized as inhering in the general nature of the judicial process that innocent bystanders might be jeopardized. Slowly, as cases multiplied in which difficulties were experienced in other areas as well, a recognition of the utility of third party participation became prevalent. ${ }^{23}$

16. Ibid.

17. See the account in Campbell, Jurisdiction and Vente Aspects of Intervention under Federal Rule 24, 7 U. Pitr. L. Rev. 1, 3-4 (1940).

18. See, e.g., Carter v. Carter Coal Co., 298 U.S. 238 (1936), and the comments thercon in Jackson, The Struggle for Judicial Supremacy 21, 153 (1941).

19. See Frank, Courts on Trial 80-102 (1950); Arnold, Sxmbols of Governaent (1935).

20. See Strawbridge v. Curtiss, supra note 15.

21. 11 U.S. (7 Cranch.) 116 (1812).

22. See, e.g., Stratton v. Jarvis, 33 U.S. (8 Pet.) 4, 9 (1834); Campbell, Jurisdiction and Vente Aspects of Intervention tinder Federal Rule 24, 7 U. PITT. L. REv. 1, 5-9 (1940).

23. See Wham, Intervention in Federal Equity Cases, 17 A.B.A.J. 160 (1931): "It has grown up almost without legitimate parentage or sponsorship. ..." See, e.g., Eliot, Interventions in the Federal Courts, 31 AMr. L. REv. 377 (1897). 


\section{Amicus Curiae and Third Party Representation of Governmental Interests}

Oddly, the amicus curiae was neither one of the early devices used to resolve the third party problem in the Supreme Court nor the most frequently utilized.:Although, given its historical origins and functions, it was unlikely to come within the pale of common law hostility to intervenors or the rule in Siratubridge, and hence might have offered an easy means for representation of outside interests, it did not, in fact, make its appearance in the Supreme Court (or federal courts generally) until after 1820 . Courts, where obvious injustice would be caused by lack of representation, allowed outsiders to intervene generally by exercise of what was called "the inherent power of a court of law to control its processes."25 No great ceremony was attendant on this; often the court merely extended the privilege of filing a brief "by leave of the court." Gradually this practice came to be controlled by a set of increasingly formal rules that were communicated more or less informally to the regular practitioners before the court, or those who habitually handled similar cases on other levels. ${ }^{26}$ It was only at a much later date that these tended to be codified.

To meet the problems caused by narrow processes in an era in which semipolitical decisions were increasingly reached, a number of devices were at hand in the law or were created. "The ways of the third party" developed by the courts in this field range widely in degrees of formality. A list suggested a quarter of a century ago included among others: (a) leave to intervene as a party or a quasi-party (growing out of early equity proceedings, the right to intervene has become more general, particularly in the twentieth century and is based in part upon legislation); (b) participation as an ancillary party; (c) petition or motion or presentation of claim on a fund; (d) amicus curiae; (e) suggestion or memo; (f) special appearance; (g) class suits.77 One might possibly add to this list taxpayer suits as some sort of elevation of third parties to participant status.

Further, in less rigorously legalistic days, when the Attorney General was permitted by law and indeed forced by circumstance to maintain a private practice, it was often possible for him to serve two masters in a case. Sometimes he could advance the cause of the United States by merely acting in the name of a party; this seems to have been the case, for example, in Gibbons $v$. Ogden. ${ }^{28}$ In other instances he might represent both the interest of the United States and obtain a fee for private activity as well. The early usages of the third party devices tended to be of these more informal sorts.

24. See text accompanying note 33 infra.

25. Krippendorf v. Hyde, 110 U.S. 276, 283 (1884).

26. Eliot, supra note 23 , at 392 . Of course, today codification is virtually required. See James Beck's lament on the absence of a distinctive Supreme Court bar in 1930, estimating the size at that time as at least 30,000. Beck, MAaY It Plense trae Court 20 (1930).

27. Hersman, Intervention in Federal Courts, 61 Axr. L. Rev. 1, 4-6 (1927).

28. 22 U.S. (9 Wheat) 1 (1824). See Klonoski, The Influence of Government Counsel on Supreme Court Decisions Involving the Commerce Power 1, 10, 10 n.3, 12 (Ann Arbor: University Microfilms) (1958). 
So, in Hayburn's Case ${ }^{29}$ in 1792, Randolph was allowed to move "ex officio" for the government, but the Court "entertained great doubt upon his right ... to proceed" in this manner. The proper mode which emerged through the years by which third parties were permitted to participate was by route of the suggestion, as in the case of The Schooner Exchange, ${ }^{30}$ or general courtesy. More formally, in 1821, Pinckney was heard upon the application of the executive in the case of The Aniable Isabella. ${ }^{31}$ As the headnote suggests, accommodation of broader interests was commencing in formal fashion, for the reporter states the meaning of the case to be that "where a case involved the construction of a treaty, the court heard a third argument on the application of the executive government of the United States." 32 In any event, all of these modes of representation merge into one another, and in various epochs have often been functional equivalents.

Even in recent years, the precise standing of a party may often be somewhat vague and differently interpreted by the parties and commentators; the line between an intervenor and an amicus curiae is often blurred. In former years the lines were even vaguer, and contradictions and anomalies were quite common.

Though other devices for representing third party interests were developed extremely early, it was not until 1821 that the amicus curiae formally made its appearance. In the celebrated case of Green $v$. Biddle, ${ }^{33}$ a decision relating to land holdings in Kentucky was made by the Supreme Court without any representation on the part of that State. Repercussions were quickly evident. Coming on the heels of a series of decisions in which federal courts had asserted federal supremacy, ${ }^{34}$ the case presented explosive possibilities. It was apparently thought best to provide some forum for opposition. Under instructions from the State of Kentucky, Henry Clay made an appearance as an amicus curiae and sought a rehearing. On March 12,1821, Clay

as amicus curiae moved for a rehearing in the cause, upon the ground that it involved the rights and claims of numerous occupants of the land. . . He stated, that the rights and interests of those claimants would be irrevocably determined by this decision of the court, the tenant in the present cause having permitted it to be brought to a hearing, without appearing by counsel, and without any argument on that side of the question. ${ }^{36}$

Faced with this peculiar behavior on the part of one of the nominal participants, strongly suggesting collusion, the Court allowed the extraorclinary procedure and granted the plea for a rehearing on petition of an amicus curiae. ${ }^{\mathrm{g} 0} \mathrm{In}$ -

29. Hayburn's Case, 2 U.S. (2 Dallas) 408 (1792).

30. 11 U.S. (7 Cranch.) 116 (1812).

31. The Amiable Isabella, 19 U.S. (6 Wheat.) 1, 50 (1821).

32. Id. at 50. Similarly, in United States v. The Late Corporation of the Church of Jesus Christ of Latterday Saints, 150 U.S. 145 (1893), "Mr. Solicitor Gencral watched the case on behalf of the United States."

33. 21 U.S. (8 Wheat.) 1 (1823).

34. See Warren, The Supreme Court in United States Histony 632-51 (1926).

35. 21 U.S. at 17.

36. Green v. Biddle, 21 U.S. (8 Wheat.) 1,17 (1823). 
asmuch as the amicus curiae is not deemed to be a party, most jurisdictions would not allow him to initiate such an important procedural motion.

Clay, again acting as an amicus curiae, was later permitted to argue the case. Again in view of the usual attitude that "an amicus curiae cannot perform any act on behalf of a party," "he acts for no one," and that "the court on the suggestion of an amicus curiae can do that only which he could do without such suggestion," this debut of the amicus curiae in the Supreme Court must be recognized as a dramatic and unusual one. ${ }^{37}$

The next major step ${ }^{38}$ in the development of amicus curiae occurred when the judges were forced, as a result of Florida $v$. Georgia, ${ }^{39}$ to articulate some of the factors involved in such participation. In that case, the request of the Attorney General of the United States to be heard was opposed by counsel for the two states, and the Court was forced to grant or deny permission on its own initiative. Defining the problem, Chief Justice Taney noted that if the United States were merely requesting to be heard, there would presumably be no problem, "for it is the familiar practice of the Court to hear the Attorney General in suits between individuals, when he suggests that the public interests are involved ... not as counsel for one of the parties . . . but on behalf of the United States." 40

Why then the difficulty in this case? The nub of the problem was that the United States had a very real interest in the case and was, by all criteria, at the very least a quasi-party in the guise of an amicus curiae. As Justice Curtis noted in a learned dissent, ${ }^{41}$ this presented a major constitutional problem with regard to court jurisdiction. While suits between states fall within the original jurisdiction of the Court, all jurisdictional grants involving the United States mentioned in the Constitution are included within the appellate jurisdiction of the Court. By allowing the United States to participate as amicus curiae, the Court was, in effect, evading the jurisdictional grants of article III which literally applied would have prevented the federal government's participation as an interested party in suits involving the Supreme Court's original jurisdiction.

37. See 35 Am. \& Eng. Ann. Cas. 193-98 (1915A); compare Green v. Biddle, supro note 36, with Campbell v. Swasey, 12 Ind. 70 (1859).

38. There were to be sure both prior and subsequent conventional uses of amicus curiac. In Ex parte Randolph, 20 Fed. Cas. 242 (No. 11,558) (C.C. Va. 1833), a representative of the United States appeared, stating specifically that "he appeared in the case at the request of the court, as amicus curiae, and did not feel himself at liberty to make any admissions." Id. at 244. He did, however, venture the opinion in passing that "it was the fashion of the times, to raise constitutional questions, and nullify acts of congress." Id. at 250.

And in Lord v. Veazie, 49 U.S. (8 How.) 250 (1850), the Taney Court allowed the suggestion by amicus curiae, and agreed that the suit was collusive. See also, In re Ah Yup, 1 Fed. Cas. 223 (No. 104) (C.C. Cal. 1878), where the entire Bar was invited to malie "such suggestions as amicus curiae as occurred to them." Ibid.

39. 58 U.S. (17 How.) 478 (1854).

40. Id. at 490 .

41. Id. at 498 . 
In spite of Justice Curtis' high standing as a jurist and the skill and logic of his position, the rest of the Court accepted the amicus curiae as an ensy road to solution of this thorny jurisdictional problem. This pattern became an accepted one, and it is today a commonplace for the United States to participate as amicus curiae in cases arising under the original jurisdiction of the Court. ${ }^{42}$

In the decades that followed, the amicus curiae device continued to be used to protect governmental interests, notably in connection with grants of land. ${ }^{43}$ The flow of litigation engendered by such programs saw the government appearing in third party guises to defend past allocations or claimed present holdings. Then, in another far-reaching development, the Taney Court in the case of The Gray Jacket ${ }^{44}$ resolved another aspect of third party representation of governmental interests caused by the appearance of more than one United States agency. In this 1867 case, the Attorney General had already been heard on behalf of the United States when the Treasury Department sought leave to be heard" in opposition on behalf of any other departments of the government, they nonetheless allowed the Treasury to be heard for two hours, since "the Court is desirous of all the light that can be derived from the fullest discus" sion." 45 This phenomenon of adverse representation by different departments of the government taking opposite stands before the Court, rather than resolution within the executive branch, was then unusual, and remains "comparatively infrequent." 46

Paralleling the courtesies extended to the United States, state interests also came to require and receive accommodation. Some of these advantages accrued to the state government through the familiar pattern of active participation of state counsel as attorneys for private litigants or by admission of state attor* neys into proceedings without formal categorization of the extent of participan tion. In 1864, for example, with the constitutionality of a state statute in isste, the Attorney General of California filed a brief.47 During the 1880's the Court began to grant leave directly to state counsel to vindicate state rights. ${ }^{48}$

Amicus Curiae and Third Party Representation of Private Interests

At the same time, and continuing until legislative clarification of the situation ${ }^{49}$-most of which occurred in this century-the Court began to expand

42. See, e.g., Colorado v. Kansas, 320 U.S. 383 (1943).

43. See, e.g., Dubuque \& Pac. R.R. v. Litchfield, 64 U.S. (23 How.) 66, 68 (1859); Platt v. Union Pacific R.R. Co., 99 U.S. (9 Otto) 48 (1879); Mining Co. v. Consolidated Mining Co., 102 U.S. (12 Otto) 167 (1880).

44. 72 U.S. ( 5 Wall.) 342 (1866).

45. Id. at 371 .

46. Note, Judicial Resolution of Administrative Disputes Betzecn Federal Agcucics, 62 Harv. L. Rev. 1050 (1949); Krislov, The Supreme Court Since 1937, Nine Judges in Search of a Role 228-33 (unpublished Ph.D. dissertation, Princeton University Library 1955). In United States v. ICC, 337 U.S. 426 (1949) the Solicitor General appeared for both sides.

47. Steamship Co. v. Jolliffe, 69 U.S. (2 Wall.) 450, 454 (1864).

48. See, e.g., Iowa v. McFarland, 110 U.S. 471 (1884); Mining Co. v. Consolidated Mining Co., 102 U.S. (12 Otto) 167 (1880).

49. See Scott, Actions at Law in the Federal Courts, 38 HArv. L. Rev. 1 (1924) for a good history of the transition from Court to legislative action, and the reciprocal im 
the right of participation of private litigants. ${ }^{50}$ At times as intervenors, at times as amicus curiae, depending on the situation and requests of the litigants or agreements of the counsel, litigants of similar cases pending before the lower courts and parties to lower court proceedings in a case before the Supreme Court who had not joined in the appeal were allowed to state their views by brief or oral presentation. Others claiming to be "real parties" in the case, or persons who could be directly injured by a decision, were sometimes extended similar privileges.

Such third party activity was not uniformly evident in all types of cases, and certain types of litigation typically had a greater complexity as regards the number of participants. ${ }^{51}$ Patent suits between the licensee and other parties often involve the holders of the patent; land cases raised similar issues to those raised in admiralty situations. Some types of cases were, strictly speaking, in rem proceedings; others approached this category in consequences. Tax cases ${ }^{62}$ and cases involving Indians and their rights ${ }^{63}$ were preternaturally involuted, presenting all types of problems in representation. In a somewhat tardy fashion, the evolving use of the amicus brief as a form of third party representation came to be reflected in the nomenclature.

Formerly, the amicus curiae stood in an essentially professional relation to the Court and organizations were not regarded as the amicus but rather the lawyer himself. Throughout the last half of the nineteenth century the Court and the briefs cling to this approach. As late as 1919 the attorneys in the Prohibition Case ${ }^{54}$ styled themselves as "both of Washington, D.C., amici curiae, and general counsel to the National Association of Distillers and Wholesale Dealers." Apparently without self-consciousness, such identifications have been totally forgotten. By the 1930's, the open identification of an amicus brief with an organizational sponsor was quite commonplace. ${ }^{.5}$

The attribution of a brief to an organization belies the supposedly lawyerlike role of the amicus, but realistically embraces and ratifies the transformation of the actual pattern of behavior and its new function. The amicus is no longer a neutral, amorphous embodiment of justice, but an active participant in the interest group struggle.

Where the stakes are highest for the groups, and where the needs on the part of the judges for information and for the sharing of responsibility through

fluence of the two processes; see also the leading articles by Mfoore \& Levi, Fadcral Intcrvention, 45 YALE L.J. 565 (1936), and 47 YALE L.J. 898 (1938), for legislation dealing with private and public intervenors.

50. Ibid.

51. See, e.g., Bate Refrig. Co. v. Hammond, 129 U.S. 151 (1889); White-Smith ALusic Co. v. Apollo Co., 209 U.S. 1 (1908), and the discussion in Northern Security Co. v. United States, 191 U.S. 555 (1903).

52. See, e.g., Strattons Independence Ltd. v. Collector, 231 U.S. 399 (1913).

53. See, e.g., Wallace v. Adams, 204 U.S. 415 (1907).

54. Hamilton v. Kentucky Distil. Warehouse Co., 251 U.S. 146 (1919). This identification is reprinted only in 40 Sup. Ct. 107 (1919) and not in the official Reports.

55. See, e.g., United States v. Butler, 297 U.S. 1 (1935). 
consultation are at a peak, access has appropriately, and almost inevitably, been at its greatest. Occasionally a lower court will refuse an amicus brief for being "excessively partisan." "68 Or, a state court will, like the Michigan court, strike its permission to participate in view of the fact that a party "is acting (tholigh under disguise) not as a friend of the court but as a friend of one of the contestant litigants before said court." "6r

The Supreme Court of the United States makes no pretense of such disinterestedness on the part of "its friends." 58 The amicus is treated as a potential litigant in future cases, as an ally of one of the parties, or as the representative of an interest not otherwise represented. At this level the transition is complete; at the other court levels it is in process. Thus the institution of the amicus curiae brief has moved from neutrality to partisanship, from friendship to advocacy.

\section{Consequences of the Shift}

However, the change from "impartial friend of the court" to acknowledged adversary has implications which go far beyond a mere shift in the use of the brief from a source of neutral information to a flexible tactical instrument available to litigants and third parties. More significantly, the increased use of the amicus brief mirrors the change in tactics and structure of interest artictlation in American politics as a whole that occurred during the latter quarter of the nineteenth century. As Harold Lasswell has noted, ${ }^{60}$ that period saw a transformation of dominant modes of interest activity. The emphasis shifted from personal, face-to-face contacts (including corruption) to impersonal, organized, and systematic, bureaucratically undertaken and oriented activity. This transformation is usually recognized only implicitly by commentators ${ }^{\text {i0 }}$ when accounted for in terms of reaction, either to industrialization or bureallcratization-that is, as the product of either the industrial or the organizational revolution.

The advantages that accrue to bureaucratically sophisticated groups in other political arenas became evident in the judicial sphere as well. Involved are such factors as: sensitivity to the possibility of raising new issues (whether for offensive or defensive purposes); the ability to mobilize resources (including

56. First Citizens Bank \& Trust Co. v. Saranac, 243 App. Div. 843, 278 N.Y.S. 203, aff'd, 246 App. Div. 672, 283 N.Y.S. 498 (1935).

57. Brief for Respondent, p. 59, City of Grand Rapids v. Consumers Power Co., 216 Mich. 409, 185 N.W. 852 (1921). The court rejected the contention made by petitioner that he was an intervenor on the basis of insufficient interest and rejected his offer to appear as an amicus curiae presumably on grounds that his interest was too partisan for him to be anything but an intervenor. Record, pp. 70-72.

58. See Universal Oil Products Co. v. Root Refrigerating Co., 328 U.S. 575 (1946), for a discussion of the outer limits which the Court may place on the efforts of an amicus curiae to serve two masters, the court and the client. Implicit in such a limit is a recognition of a norm of partnership for amici curiae.

59. Lasswell, Book Review, 107 U. PA. L. Rev. 295 (1958).

60. See, e.g., Blaisdect, American Democracx Under Pressure (1957); ScuruftGIESSER, THE LOBBYISTS (1951). 
human resources), and to bring to bear expertise, memory, or files; and the organizational flexibility to respond quickly and sensitively before policy is set. These are vital in all political matters, and in this the legislature, judiciary, and administration remain similarly responsive. Perhaps the first consistent utilization of the amicus brief's potential as a form of judicial lobbying can be attributed to the Department of Justice.

The formation of the department in 1871 meant that broader vindication of governmental rights was feasible. With the increase of staff came the development of a broader "public interest" approach to government litigation, which supplanted an attitude of emergency vindication only where absolutely necessary. ${ }^{61}$

Charles J. Bonaparte's administration as Attorney General (1906-09) was a particularly aggressive one with far-reaching developments in cases involving Negro rights and vindication of federal legislation before the courts. ${ }^{62} \mathrm{He}$, if anyone, seems to have been the innovator of a positive use of governmental amicus briefs, not merely to vindicate specific statutes, but with a broader aim of effectuating major social changes and implementing broad public policies. Specifically, the United States as a third party actually was the principal litigant in such cases as the Employer Liability Cases ${ }^{13}$ and Bailey v. Alabama."4 And Bonaparte, after retirement from office, personally figured as an important ally in Buchanan $v$. Warley, ${ }^{65}$ which tested the constitutionality of at-

61. See Easly-Sartre, The Departarent of Justice (1904), and Klonoski, The Influence of Government Counsel on Supreme Court Decisions Involving the Commerce Power (Ann Arbor: University Microfilms 1958).

62. Moody, who was Bonaparte's predecessor, as attorney genemal had tended to concentrate on Supreme Court action. At the time of his elevation to the Supreme Court Moody concluded that an even more intense focus would have been rewarding, and following that advice, Bonaparte in twenty-seven months conducted fifty-six cases before the highest tribunal, and personally argued forty-nine of them. Bonaparte, Experiense of a Cabinet Officer Under Roosevelt, 79 CeNtURy MLagazine 752 (1910).

63. 207 U.S. 463 (1908). The conclusion that the United States was, in fact, the principal litigator is derived from a mumber of factors. Bonaparte's 114-page brief amicus completely dwarfs the skimpy argument of the nominal litigants. Another indication of such participation appears both here and in Johnson v. South Pacific Co., 196 U.S. 1 (1904). In both instances the printing order numbers indicate that the litigants' briefs and those of the United States as amicus (in the latter case as a "suggestion") were printed together. The numbers on the Employer Liability Cases were 22410-07 for plaintiffs, 22411-07 on the government brief. The briefs in both instances were filed or the same day. No records are available to show whether government briefs were continuously printed at the Government Printing Office during the period involved. Letter from E. E. Aforsberger of the U.S. Government Printing Office, Jan. 7, 1960.

64. 211 U.S. 452 (1908); 219 U.S. 219 (1911). Wickersham for the Tait Administration continued aggressively with the case, and the U.S. brief sustains the major part of the legal argument.

65. 245 U.S. 60 (1917). Charles Bonaparte wrote a series of articles in the Baltimore Sun that was strongly relied on and quoted extensively in the amicus brief of the Baltimore NAACP. Brief of Baltimore NAACP as Amicus Curiae, pp. 24-30, Buchanan v. Warley, supra. The case seems to have been a perfect forerunner of subsequent civil rights litigation, down to participation of various neighborhood "welfare associations," a group of legal 
tempts to establish Negro ghettos through local legislation. The practice of governmental appearances in significant public causes, where very broad social problems and a generalized public interest are involved, has become standard procedure-as illustrated by such cases as the school segregation, racial convenant, and redistricting litigation.

One major development which has contributed to the use of the amicus brief has been the emergence of administrative agencies. The regulatory agencies enforcing and establishing administrative policies have necessarily been involved with a broad complex of interests. Their policies, in turn, affect a broader skein of interests, both in direct and indirect fashion, than those of the older executive agencies. In short, the activities of these agencies have involved potential interests and actual participants beyond the normal course of individual social and political interaction with governmental agencies. ${ }^{60}$ The fact that this has been explicitly recognized has also reinforced the trend. Many administrative agencies, acting by legislative provision or on their own initintive, have broadened the base of official participation in hearings before them. They, thus, have mobilized and alerted groups to issues and stakes involved at a stage prior to judicial litigation. So alerted, groups and individuals have sought means of strengthening favorable policies, both at the administrative level and at the judicial level. ${ }^{\text {tr }}$

A transitional link between governmental agents acting as interest articulators and private interest group activity in the judicial sphere was the participation of government officials in the guise of organized groups. So, in 1913 the railroad commissions of eight states were conjoined in a single amicus curiac brief. $^{.8}$ The 1916 term of the Court saw the National Association of Attorneys General participate in cases, as well as groups of attorneys general.60

scholars advocating Negro rights, and the accusation by the City of Baltimore as amicus curiae that "outside agitation," notably by Senator Clapp of Minnesota, had really fostered the litigation.

66. For some of the interest group complexities caused by administrative prograns, see, e.g., Comer, Legislative Functions of National Admunistrative Authorities 198-270 (1927). Cf. Huntington, The Marasmus of the ICC, 61 YALE L.J. 467 (1952). The Huntington indictment and the notion of interest groups as capturing such agencies, found throughout political science literature, has some connotations of an a priori analysis; note that, as early as the twenties, progressives opposed creation of a Commerce Court on the ground that it would be controlled by special interests. See Frankfurter \& Landrs, The Business of the Supreme Court 157 (1928).

67. In some instances governmental agencies may only participate as third parties, with the U.S. Department of Justice entrusted with the real responsibility of litigation. Sce Stern, "Inconsistency" in Government Litigation, 64 HARv. L. REv. 758 (1954). The ICC recognizes, for example, the right of complaint of any person, company, mercantile organization, manufacturing society, body politic, municipal organization, carrier, or state commission. See Sharfaran, Tue Interstate Connserce Commission 152 (1931). Even the process of adjudication and the opinions of the commissioners encourage litigants. Sec Mason, The Language of Dissent 28 (1959).

68. Minnesota Rate Cases, 230 U.S. 352 (1913) ; Missouri Rate Cases, 230 U.S، 474 (1913).

69. Caldwell v. Sioux Falls Stock Yards Co., 242 U.S. 559 (1917) ; and Hall v. GeigerJones Co., 242 U.S. 539 (1917), where both the National Association of Attorneys Gencral 
Among the private interest groups which were the first to utilize the opportunities of broader access were racial minority groups, securities and insurance interests, railroad interests, and miscellaneous groups under severe attack, notably the liquor interests in the first quarter of this century. Sheer familiarity with the intricacies of the existing system, strong dissatisfaction with it, and relative desperation seemingly can all function as sufficient motives for the seeking out and the finding of new channels of influence for self-protection or aggrandizement.

The first example of minority group activity appears to have been the participation of the Chinese Charitable and Benevolent Association of New York in immigration cases. Beginning in the 1904 case of Al How (alias Louis Ah How) v. United States, ${ }^{70}$ Mr. Max J. Kohler was to intervene in such cases, explaining that:

The peculiar character of these Chinese Exclusion cases, involving arrests or exclusions of Chinese persons, frequently indigent travellers far from their home, and beyond the convenient reach of relatives and friends, as well as of witnesses in their own behalf, has made it desirable for the Chinese persons of the City of New York, and its immediate vicinity, by concerted action and mutual aid, to assist each other ... and accordingly at or about August 1, 1903, your petitioning corporation did retain Mr. Max Kohler ... to defend Chinese persons arrested within or prevented from entering the United States. . . .

Moreover, the identification of the NAACP with such briefs is not merely a contemporary one, for that organization has, almost from its inception, participated as amicus curiae in litigation. An early case in point is Guimn $v$. United States, ${ }^{72}$ the famous Grandfather Clause case, where the NAACP justified its participation on the grounds that "the vital importance of these questions to every citizen of the United States, whether white or colored, seems amply to warrant the submission of this brief."73

Highly regulated groups also were early participants. Since before the turn of the century, ${ }^{74}$ litigation involving the ICC regulatory powers has involved extensive non-party participation of interest groups (though not necessarily as amicus curiae). ${ }^{75}$ Following the principle enunciated by Merle Fainsod that interest structure often arises in response to governmental patterns, ${ }^{70}$ the transportation industry has continued to be the most highly and intricately organized

and the Investment Bankers Association of America filed briefs; and Utah Power \& Light v. United States, 243 U.S. 389 (1917).

70. 193 U.S. 65 (1904).

71. Brief for the Chinese Charitable and Benevolent Association of New York, as Amicus Curiae, p. 2, Ah How v. United States, supra note 70.

72. 238 U.S. 347 (1915).

73. Brief for NAACP as Amicus Curiae, p. 2, Guinn v. United States, sipra note 72.

74. See, e.g., ICC v. Cincinnati, N.O. \& T. Pac. Ry. 167 U.S. 479 (1897).

75. See, e.g., ICC v. Chicago, RI. \& Pac. Ry., 218 U.S. 88 (1910) (Seventeen organizations participated in a single amicus curiae brief).

76. Fainsod, Some Reflections on the Nature of the Regulatory Process, 1 Punurc Poticy 296, 299 (1940). 
area of the interest group spectrum. Not only has there been continued representation paralleling the political struggles of the railroad with the trucking interests, of railroad management with laborers, or even individual members with leaders; but also the report of Noble $v$. United States ${ }^{77}$ records the appearance on opposite sides of the fence of both the Regular Common Carriers Conference of the American Trucking Association and the Contract Carriers Conference of the ATA.

While stockholders, committees, and rival companies began to participate as third parties in the last quarter of the nineteenth century, organized financial groups and associations became active later, noticeably appearing in the Court after about $1917 .{ }^{78}$ Hamilton v. Kentucky Distil. Co., ${ }^{70}$ involving the constitutionality of liquor prohibition, saw participation of interested organizations in 1919, as did Pacific St. Tel. \& Tel. Co. v. Oregon ${ }^{80}$ in 1912, with public service and ideologically oriented groups being the principal actors.

The transitional dates tend to cluster closely about the time of Brandeis' effective use of a separate brief on behalf of the National Constumers' League in Muller v. Oregon ${ }^{81}$ in 1908. It is difficult to assess how strong a causal relationship there was, for Brandeis insisted on appearing for the State of Oregon, and as far as the Court was concerned, there were no indications of his being in reality an amicus curiae. Such an arrangement was, for Brandeis, a condition of his participation in that "the status of appearing as an official participant on behalf of the state seemed to him an important element of strength for the defense." 82 However, as early as 1916, Frankfurter called attention to the fact that Brandeis' role was essentially that of amicus curiae. ${ }^{83}$

Yet another type of interest was to be heard from. In 1925 the Mycrs case, 84 which tested the limits of legislative control over the power of executive appointment and removal, presented peculiar dilemmas of representation. Legislative interests were presumably to be defended by the plaintiff, and the executive position directly by the Department of Justice. Quite naturally Congress was restive under the arrangement, and the President Pro Tem of the Senate and the Chairman of the House Judiciary Committee were conferring with regard to possible action, when the Court, apparently on its own initiative, appointed George Wharton Pepper as amicus curiae to present the congressional

77. 319 U.S. 88,89 (1943).

78. See note 69 supra. At least so far as I have been able to determine, these cases mark the first instances of such appearances.

79. Hamilton v. Kentucky Distil., 251 U.S. 146 (1919).

80. 223 U.S. 118 (1912). Among others, briefs were filed for The American Burcat of Political Research and the People's Rule League of America.

81. 208 U.S. 412 (1908).

82. Mason, The Language of Dissent 248 (1959); Vose, The National Consumers League and the Brandeis Brief, 1 Midwest J. PoL. Scr. 267 (1957); GoldasARK, IMPNTIENT CRusader 163 (1953).

83. Frankfurter, Hours of Labor and Realism in Constitutional Lanw, 29 HANv. L. REv. 353, 372 n.63 (1916).

84. Myers v. United States, 272 U.S. 52 (1926). 
point of view. ${ }^{85}$ Such legislative representation has been employed periodically since that time, including an extended oral presentation on one occasion by the Chairman of the House Judiciary Committee. ${ }^{86}$

Thus, by the mid-nineteen-twenties, these major types of political interests had all witnessed at least one major instance of representation before the United States Supreme Court. Throughout the subsequent years the number of cases in which such briefs were filed grew in number, as did the number of such briefs filed in cases. ${ }^{87}$ By the nineteen-thirties, such briefs were commonplace, and by the late nineteen-forties they were beginning to be regarded by the Court as potential sources of irritation. At the same time they were increasingly of significance to the outcome and were even cited on occasion as justification for the granting of certiorari.88

While a series of "discrete and insular minorities" of a fiscal and commercial nature early found the amicus curiae brief a useful and potent instrument, it was the use of the device by civil rights organizations which drew widespread public attention. The American Civil Liberties Union was most active in this, as in other aspects of fostering minority group activity. In accordance with its standard policy of developing groups so as to encourage self-defense, the ACLU has characteristically contracted its activities as each minority group has become capable of handling its own litigation, participating only by invitation. ${ }^{89}$

85. See N.Y. Times, Feb. 3, 1925, p. 2, col. 2, and Franffurter \& La:idis, ThE BUSINESS of THE SUPREArE Courr 311-12, for accounts of the Myers case. Further political interest representation was secured in Secretary of Agriculture v. Central Roig Refining Co., 338 U.S. 604 (1950). Puerto Rico was here allowed to intervene formally to protect its interests after an effective plea that pointed out that: "Puerto Rico has no access to the political process .... In the Congress the territory has only a Resident Commissioner, who by courtesy of that body-there is no law on the subject-is indulged in a seat in the House of Representatives but has no vote. As a 'discrete and insular minority' ... the prople of Puerto Rico must depend upon the courts." Memorandum for the Government of Puerto Rico, p. 21.

86. See Jurney v. MacCracken, 294 U.S. 125, 128 (1935), for presentation by Representative Hatton W. Sumners. In Mfurdock v. City of Memphis, 87 U.S. (20 Wall.) 590 (1875), Mr. Philip Phillips orally, and Mr. B. R. Curtis through a brief written before his death, participated as friends of the court. Wiener's statement that Pepper's appearance was the only instance of oral presentation by an amicus curiae other than the Attorney General is in error. Wiener, The Supreme Court's New Rules, 68 HARv. L. Rev. 20, 81 n.303 (1954). See also Robertson, Appenlate Practice and Procedure in the Supreine CoURT OF THE UNITED STATES 201-02 (1929).

87. Harper \& Etherington, Lobbyists Before the Cosurt, 101 U. PA. L. REv. 1172 (1953).

88. See Harper \& Etherington, Lobbyists Before the Court, 101 U. PA. I. REv. 1172 (1953) ; Wiener, The Supreme Court's New Rules, 68 HARv. L. REv. 20 (1954); Sonnenfeld, Participation of Amici Curiae ... 1949-1957, Workmng Papers in Researce MietrodoLoGY No. 3 (mimeo. Michigan State University) (1958), for instances of abuse by amici curiae. See Pennsylvania v. Nelson, 350 U.S. 497 (1956), and Georgia v. Evans, 316 U.S. 159 (1942), for instances where amici curiae were cited as evidence in justification for granting review.

89. See Private Attomeys-General: Group Action in the Fight for Civil Liberties, 58 YALE L.J. 574, 579 (1949). 
Thus, numerous organizations which developed under ACLU tutelage are now largely independent in orientation and activities. Despite sharp differentia" tion in attitudes toward, and methods of, litigation, some lessons of legal strategy have remained a common legacy of the various civil rights groups. They also have retained some minimal cohesion in many of the efforts to affect court rulings, as well as in their political activities, although hardly to the extent sometimes portrayed by opponents. ${ }^{90}$

Vose has shown that by informal and nonsystematic cooperation civil rights groups did tend to coordinate their activities in the conduct of litigation, although the vagaries of chance and the actions of legal participants often thwarted any of the vague efforts at coordination. ${ }^{01}$ An increased reliance on litigation as a means of vindicating minority rights otherwise difficult to obtain through the political process, however, resulted in civil rights organizations such as the ACLU, and the American Jewish Congress, being among the most active filers of amicus curiae briefs over the past few years. ${ }^{22}$ In addition, labor organizations have been active, and not only in labor cases. ${ }^{03}$ Important civil rights cases such as the desegregation decision or the restrictive covenant cases saw a turnout of large numbers of amicus curiae briefs from varying minority group organizations. All of this focused attention and provoked criticism of the amicus curiae brief. ${ }^{94}$

Such briefs reached an apex of notoriety and criticism during the last half of the forties and the early fifties. A previous rise in the number of filings was a major factor in this criticism. In a classic instance, Laweson $v$. United States, the problem of the Hollywood "unfriendly ten" evoked attention through amicus curiae briefs from forty organizations. Left-wing groups were both aggressive and open in their efforts to exploit the increased significance of this aventue to interest participation. The National Lawyers Guild, for example, both was and is a major filer of amicus curiae briefs. The relation of the amicus brief to standard pressure group tactics has been made even more overt. Thus, the Communist Daily Worker has called upon individuals to file "personal" amicus curiae briefs by writing letters directly to the Justices. ${ }^{96}$ Clearly, amicus briefs are merely the most formal of a number of lobbying tactics which include other devices such as the picketing utilized during the trial of Communist Party leaders under the Smith Act in New York City. Similarly in 1953, petitions were circulated by the National Committee to Secure Justice in the Rosenberg Case. A campaign of telegrams was part of the effort to save the life of Willie McGee, who had been

90. See Krislov, Book Review, The New Leader, April 11, 1960, p. 25.

91. Vose, Caucastans Only ch. 4-8 (1959).

92. Sonnenfeld, Participation of Amici Curiae by Filing Briefs and Presenting Oral Argument in Decisions of the Supreme Court, 1949-1957 11, 16 (Michigan State Univer* sity Governmental Research Bureau, 1958).

93. See, e.g., Shelley v. Kraemer, 334 U.S. 1 (1948).

94. See Wiener, The Supreme Court's Nezu Rules, 68 Harv. L. Rev, 20 (1954).

95. 176 F.2d 49 (D.C. Cir. 1949), cert. denied, 339 U.S. 934 (1950).

96. Harper \& Etherington, Lobbyists Before the Cottrt, 101 U. PA. L. REv. 1172-73 (1954). 
sentenced to death in Mississippi. Mr. Justice Black, who had been generally sympathetic to interest group expression, found this a repugnant development and condemned the "growing practice of sending telegrams to judges in order to have cases decided by pressure." He refused to read them and noted that "counsel in this case has assured me they were not responsible for these telegrams." ${ }^{17}$

The lack of discreetness here-the ignoring of the traditions and practices of the judicial process-has even been demonstrated by attorneys. Wiener characterizes a brief in Gironard $v$. United States as purposely ignoring in its preoccupation with propaganda the decisive issue on which the case turned.98 Similarly, the American Newspaper Publishers brief in Craig v. Harncy evoked from Mr. Justice Jackson a strong response indicating that he thought its emphasis on the size and power of the constituent newspapers was neither of legal significance nor an accident but simply intimidation. (In fairness, it should be noted that size and distribution of membership is relevant to any showing of interest in an instant case and even amicus curiae briefs are expected to represent a specific rather than a diffuse interest.)

The question of the proper relationship of an amicus to the principal party and the principal argument is a complex one. In the modern context of partisan "neutrality" the amicus' orientation is a peculiar one and it has been a tenet of proponents of the need for restrictions that the modern amicus briefs have lacked a well defined rule. A simple endorsement of a basic brief adds nothing to the cause except the prestige of the group making the endorsement. This is to invite the charge of political pressure. On the other hand concentrating on purely legal argument has its problems as well. Some amicus curiae briefs have, of course, been of great legal guidance to the Court-Mr. Justice Frankfurter relied greatly upon the Synagogue Council of America brief in the $M c$ Collum case, for example. ${ }^{100}$ This, however, occurs generally when there is evidence of some weakness in the legal talent arrayed by the principal party, or when the interest of the amicus curiae is, in fact, very sharply differentiated from that of the litigant. These cases are not the run-of-the-mill ones. In most instances the situation is less stark and the considerations more complex. ${ }^{101}$

Where there is relatively adequate representation of the basic points of view, the amicus curiae, however, may perform a valuable subsidiary role by introducing subtle variations of the basic argument, or emotive and even questionable arguments that might result in a successful verdict, but are too risky to be embraced by the principal litigant. The strategy here is the reverse of that utilized by Brandeis-instead of identifying new techniques with a litigant's official position, it may very well be advantageous to label the new as unofficial so that, if it should be rejected, a minimum of disapprobation attaches to the

97. Vose, Litigation as a Form of Pressure Group Activity, 319 Annals 29 (Sept. 1958) ; N.Y. Times, March 16, 1951, p. 23, col. 4.

98. Wiener, The Supreme Court's New Rules, 68 HARv. L. Rev. 20, 80 n.296 (1954).

99. 331 U.S. 367,397 (1947).

100. McCollum v. Board of Education, 333 U.S. 203, 229 n.19 (1948).

101. See generally Harper \& Etherington, sipra note 96. 
official cause. Arguments that might anger the Justices, doctrines that have not yet been found legally acceptable, and emotive presentations that have little legal standing can best be utilized in most instances by the amicus rather than by the principals. The NAACP, for example, suggested the overruling of Plcssy v. Ferguson as an amicus curiae in Henderson v. United States. ${ }^{102}$ And sometimes such suggestions bear fruit. For example, the ACLU amicus curiae brief was apparently influential in the overturning of Wolf $v$. Colorado. ${ }^{103}$

The considerations involved in such supplementary usages of the amicus curiae brief are admirably portrayed in the discussion between Charles Abrams and Newman Levy of the American Jewish Committee in connection with the restrictive covenant cases. When asked his views of a prospective brief to be filed by the American Jewish Committee, Abrams wrote:

It is an excellent "main brief" written with your fine straight style. But I question the adequacy of its emphasis as a brief antici.

I have always viewed the function of the amici to take up and emphasize those points which are novel or which if stressed in the main brief, might dilute or weaken the main forceful arguments.

I never thought there was much cumulative force in the repetition of logic by eighteen briefs. Unlike good poetry, repeated it has a tendency to bore. But a weak legal argument, with a moral quality, forcefully presented by an "outsider" will not detract from the force of the main argument....

The amici should be providing the arguments that will salvage the judges' consciences or square with their prepossessions should they lean toward holding for us. ... .

Play up what entailment of all land would mean socially. Use the relevant references by Gunnar Myrdal ; give the British background for exclusion of non-conformists and their migration to America where the freehold and the fee simple became one of our earliest and greatest traditions. Show how Jefferson and the states immediately after Independence adopted laws excluding primogeniture and entail. ... May people band together to bar a race from food and clothing? These are a few of the important irrelevancies that occur to me.

Why desert all these rich and adventurous passages to jam the safe waters that should be reserved for the main advocates? ${ }^{104}$

But the strategies for the amici may be different from the strategies of those interested merely in winning the case. This is suggested by Newman Levy's reply:

I thoroughly agree with everything you say about the function of an amicus brief. So far as the court is concerned I am inclined to think that it is pretty much like an endorsement on a note. Its purpose is to tell the court that we agree with the appellant and we hope it will decide in his favor....

When this brief was first contemplated I discussed it with my legal committee, and they agreed that I should confine myself exclusively to this

102. Brief for NAACP as Amicus Curiae, Henderson v. United States, 314 U.S. 625 (1941).

103. For the role of the amicus curiae and of the principal litigant sce the dissenting opinion of Mr. Justice Harlan, Mapp v. Ohio, 367 U.S. 643, 675 n.5 (1961).

104. Vose, Caucastans Only 166-67 (1959). 
constitutional question. That was why I omitted the sociological stuff, the United Nations Charter and the rest of it. You see, if the Supreme Court should happen to mention in its decision that restrictive covenants are illegal upon the authority of Buchanan v. Warley, we will be able to say to our members, "Isn't that exactly what we told the court?"105

Thus the function of the amicus can be viewed as simply one of endorsement, or it can be seen also as part of the supplementary strategies available to the principal litigants.

Whether or not the tactical potential of the amicus brief is realized in any given suit will ultimately depend on the rules of the Court governing the filing of amicus petitions and the willingness of the Court to permit the filing of any given brief. Prior to 1937, there appears to have been no written rule on the subject of the filing of an amicus curiae brief, and leave of the Court was necessary for filing. ${ }^{108}$ The specification in that year that litigating parties must give consent to nongovernmental amicus briefs made no real difference in practice. Prior to the adoption of the rule, it had been standard procedure to request permission from the parties. In the absence of such consent, leave to file was easily obtained from the Court in almost every instance both before and after promulgation of the rule.

The change of 1949, on its face, seemed to liberalize the rules. It recognized the existence of briefs filed by order of the Court without consent of the parties -a procedure which had not been formalized in previous rules. Since such filings had, as we have seen, been standard, the more significant indicator for future practice was the intimation that amicus briefs and motions to file would have to be submitted within "a reasonable time" prior to decision, indicating some dissatisfaction with dilatory filing of such briefs in the past. Further, the brief for motion to file was to be a separate document from the brief on the merits, permitting the Justices to avoid wading through the entire argument before deciding whether such a brief was to be permitted their attention. Even more direct and succinct was the Court's reaction to applications to file without consent of the parties: "Such motions are not favored."107 Although a technical reading of the. rules (now Rules 42(1) and 42(2)) indicates disfavor only for motions to file on the jurisdictional question or for petitions for a writ of certiorari without party consent and do not extend this disfavor to amicus curiae briefs on the merits, in practice it has appeared that the disfavor obtains equally in both instances. ${ }^{108}$

The result was quite marked. In the 1948 term prior to the new rule, fourteen briefs were filed without party consent, while the Court denied permission to file only three such briefs. With the new attitude of the Court, the five terms following promulgation of the rule saw denial of leave to file without party con-

105. Id. at 167 .

106. Robertson, Practice and Procedure in the Supreare Cougt of the Unitted States 200 (rev. ed. 1929).

107. Sup. Ct. Rules 27:9(b), 338 U.S. 959 (1949).

108. Comment, The Amicus Curiae, 55 Nw. U.L. Rev. 469, 475 (1960). 
sent in thirty-nine instances, while in only twelve instances was permission granted. 109

Equally significant was the interpretation of the new mood of the Court by the Solicitor General. Since approximately fifty per cent of the cases before the Court involved the United States as a party, his agreement to the filing of briefs was a vital determinant of the extent of amicus participation if the Court was to continue to deny the bulk of requests for filing without permission of parties. Prior to 1949, his consent was, like that of the Court, almost attomatic, but after the new rule his refusal became completely automatic. ${ }^{110}$ The Court's attitude and the Solicitor General's interpretation drastically reduced participation of amicus curiae. In 1949, 118 briefs were filed in fifty-three cases, and on eleven occasions oral argument by amicus curiae was permitted. In 1950, thirty-six cases only saw 70 briefs, and in 1951, there were only thirty cases with such briefs, with only forty-four amicus curiae allowed to participate. ${ }^{111}$

However, in 1952, the Solicitor General's attitude was subjected to sharp criticism emanating from different conceptions of the proper role of the amicus curiae held by Justices Black and Frankfurter. On the one hand, Mr. Justice Frankfurter expressed dissatisfaction with the Solicitor General's actions for the somewhat paradoxical reason that under the rules denial of permission of leave to file became the responsibility of the parties to the litigation. ${ }^{\mathbf{1 1 2}}$ It would not do, Frankfurter argued, for the Solicitor General to refuse permission automatically in response to what he saw as an attitude of the Court, since the effect of such denial was to continue to put the burden on the Court to distinguish between proper and improper briefs. ${ }^{113}$ Thus Mr. Justice Frankfurter further emphasized the sharp departure from notions of the neutrality of the amicus curiae that the rule entailed by making clear the primary responsibility of the parties for inclusion or exclusion of briefs before the Court.

While Mr. Justice Black concurred in Lee v. United States with Mr. Justice Frankfurter's dissatisfaction with the policies of the Department of Justice, his agreement was only superficial. Mr. Justice Black agreed that the Solicitor General ought not to withhold consent automatically, but essentially he regarded the Court rule as needlessly restrictive. Thus, his criticism of the Solicitor General was that he had further restricted a restrictive rule and his primary complaint was against the Court itself. This position is further spelled out in his dissent to the reformulation of the Court's 1949 rule in 1954. In an objection to an order adopting generalized rules for the Court which stubstantially recodified the 1949 changes, Mr. Justice Black declared :

109. See table at note 119 infra.

110. See Lee v. United States, 344 U.S. 924 (1952); United States v. Lance, Inc,, 342 U.S. 915 (1952). See also Schubert, Constitutional Polutrcs 77 (1960).

111. Sonnenfeld, Participation of Amici Curiae by Filing Briefs and Presenting Oral Argument in Decisions of the Supreme Court, 1949-1957 (Michigan State University Governmental Research Bureau) 4, Table 1 (1958); Schubert, QunNtitative Aspecrs of Judictal BeHaVtor 74-75 (1959).

112. See Lee v. United States, 344 U.S. 924 (1952) ; United States v. Lance, Inc, 342 U.S. 915 (1952).

113. United States v. Lance, Inc., 342 U.S. 915 (1952). 
I have never favored the almost insuperable obstacle of rules put in the way of briefs sought to be filed by persons other than the actual litigants. Most of the cases before this Court involve matters that affect far more than the immediate record parties. I think the public interest and judicial administration would be better served by relaxing rather than tightening the rule against amicus curiae briefs. ${ }^{114}$

The Solicitor General in response to criticism modified his policies in 1952, and in 1957 his office issued a statement of policy defining the standard governing grant or denial of consent. The Department of Justice frowns upon the filing by amici with merely an academic interest at one extreme, or those who merely wish to engage in propaganda on the other. Consent is given "where the applicant has a concrete, substantial interest in the decision of the case, and the proposed brief would assist the Court by presenting relevant arguments or materials which would not otherwise be submitted." This change in position does not, of course, restore pre-1949 ease of filing and for several years, no great change in rate of filing of briefs resulted from this relaxation of policy. 115

The 1954 rule changes essentially reorder the 1949 provisions with minor exceptions. The separate printed motion for leave to file is explicitly limited to five pages as opposed to the 1949 rules provision that it "concisely state" matters. In addition, a new rule-rule 44-provides that the time for oral amicus curiae presentations made with consent of a party will be taken out of the allotment for the consenting party. Both changes are essentially, though not signifcantly, restrictive, but together with the re-enactment of the rest of the 1949 rules, they provide strong evidence that Mr. Justice Black's position with regard to filing was then repudiated and Mr. Justice Frankfurter's point of view upheld. 116

The reasons are not hard to understand. Mr. Justice Black to the contrary notwithstanding, the present rules do, in fact, allow broad representation of interests, while at the same time providing for a minimum of Court responsibility. The delegation of scrutiny of the briefs not only saves time, but also transfers the "friendship" of the participating interests to the litigating parties.

One effect of the Court rule is to transfer some of the responsibility over amicus curiae briefs to the litigant and therefore to aid the principal litigant in the formulation of his strategies-provided he can convince the amicus to cooperate. The Court attitude also permeates outward to the amici who, like the American Jewish Congress, adopt the view that they will examine their participation closely and "have been deterred from taking any action by the unlikelihood of either obtaining consent or getting permission from the court."118 The rules and their enforcement are, then, only part of the picture. The Court

114. Order Adopting Revised Rules of the Supreme Court, 346 U.S. 947 (1954).

115. Sonnenfeld, supra note 111, Appendix $C$ (contains the text of the Solicitor General's statement of May, 1957). Discussed in ScBUBERT, op. cit. supra note 111, at 72-73 and Vose, Litigation as a Form of Pressure Gronp Activity, 319 Annals 29 (Sept. 1958). See also Weiner, supra note 94, at 80-81.

116. See note 114 supra.

117. Harper \& Etherington, stpra note 96 , at 1175. 
can in many cases effect its policy without having to deny permission to file briefs. With its clearly stated residual powers to grant or deny permission, and its unformalized power to invite amicus curiae to file briefs, the Court is fundamentally in control of the filing under the new rules, while nonetheless pleasing those of the bar who had called for restriction. In addition, the knowledge of deadlines and the likelihood of scrutiny by professionals prior to filing may improve the quality of such amicus curiae briefs. However, briefs containing divergent points of view and new issues are not likely to obtain approval of the parties. ${ }^{118}$ All of this, of course, continues and accentuates the trend toward delegation by the Court of the problem of control to litigants.

However, if the small number of refusal of permissions to file by the Court and its recent generosity in granting leave to file provide any basis for judgment, a new equilibrium has apparently been reached. The trend is difficult to document because it is virtually impossible to obtain data on refusal by private parties of permission to file except in the case of so prominent and regular a participant as the Solicitor General. One cannot even take the record of applications to the court for permission to file in the absence of approval by the parties, since application to file is a function of preception of Court attitude toward the filing of such briefs as well as the refusal of the parties in the first instance.

On the other hand, the post-1949 record of denial of permission by the Court has never been excessive. At its maximum it was seventeen; it has, on the whole, been declining steadily since 1955 . During the 1961 term it reached a level that has not been seen since prior to the 1949 rules-permission to file was denied only twice. At the same time the number of briefs filed has also risen stendily to pre-1949 heights. ${ }^{119}$ Seemingly the newest figures portend a new attitude.

118. See Comment, The Amicus Curiae, 55 Nw. U.L. Rev. 469, 476 (1960). However, the proposition that in practice permission by the Court is "rarely granted," $i d$. at 475 is belied by the actualities. See table at note 119 infra.

119.

Trends in Fining, Granting and Denial of

Brtefs Amicus and Oral Participation, United States Supreare Court 1949-1961 TERMS*

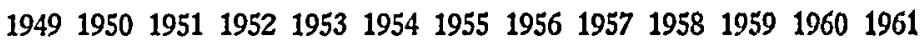

Cases

$\begin{array}{lrrrrrrrrrrrrr}\text { Cases } & \mathbf{5 3} & 36 & 30 & 39 & 20 & 47 & 41 & 39 & 43 & 63 & 43 & \mathbf{5 7} & 54 \\ \text { Briefs } & 118 & \mathbf{7 0} & 44 & 64 & \mathbf{3 4} & \mathbf{5 7} & \mathbf{7 4} & \mathbf{6 9} & \mathbf{6 4} & \mathbf{8 5} & 64 & \mathbf{9 7} & \mathbf{1 0 7} \\ \text { Oral Argument } & 11 & \mathbf{3} & \mathbf{3} & \mathbf{3} & \mathbf{7} & 20 & \mathbf{3} & \mathbf{1} & 2 & \mathbf{3} & \mathbf{5} & 4 & \mathbf{7} \\ \text { Motions Granted } & \mathbf{1} & \mathbf{3} & \mathbf{2} & \mathbf{3} & \mathbf{3} & \mathbf{0} & \mathbf{5} & \mathbf{1 8} & \mathbf{1 0} & \mathbf{1 2} & \mathbf{1 9} & \mathbf{2 7} & \mathbf{2 7}\end{array}$
(briefs)

$\begin{array}{llllllllllllll}\text { Motions Granted } & 11 & 3 & 3 & 3 & 3 & 7 & 3 & 0 & 2 & 0 & 1 & 0 & 4\end{array}$ (oral)

$\begin{array}{llllllllllllll}\text { Motions Denied } & 0 & 1 & 16 & 16 & 6 & 11 & 17 & 8 & 6 & 13 & 10 & 9 & 2\end{array}$ (briefs)

$\begin{array}{llllllllllllll}\text { Motions Denied } & 0 & 0 & 0 & 0 & 0 & 1 & 5 & 6 & 1 & 1 & 0 & 0 & 0\end{array}$ (oral)

*Sources of this table include U.S. Reports; Somnenfeld, supra note 111, Table 1; and SCHUBERT, op. cit. supra note 111, at 74-75. 
One insight to be drawn from a study of the amicus brief-and more particularly, the dispute between Justices Black and Frankfurter-is the extent to which the brief's use may mirror the controversy over the Court's lawmaking function - a controversy presented in oversimplified terms by the phrases judicial "activism" and "passivism." To the extent that Mr. Justice Frankfurter favors returning control over amicus briefs to the litigating parties, he reflects a belief that the amicus device should serve its function solely within the framework of the adversary model. Similarly, to the extent that Mr. Justice Black resists such restraints, he is supporting a broadening of the interests likely to come before the Court and the issues presented to it for resolution. Under such a modified adversary system, the brief as a form of information gathering may provide the judicial counterpart of lobbying and congressional hearings in the legislative process. And the Court's attitude, practices, and rules regarding the granting of premission to file amicus briefs may indicate the extent to which it desires to engage in quasi-legislative activities and to depart from a role of narrowly resolving adversary disputes.

This function of the amicus brief as an aid to judicial law making finds a logical counterpart in the utilization by the Court of its power to request the submission of amicus briefs. This power has been lately used, most dramatically, in the realm of desegregation where the courts have openly assumed the task of formulating and implementing constitutional mandates. While the power, as we shall see, has long been used in a variety of situations, its recent use once again belies any static conception of the amicus curiae.

The participation of the amici need not be at their own initiative. A court may request participation on its own. The Solicitor General of the United States and representatives of other governmental units are regularly invited to participate and file a brief. From time to time individuals with specialized knowledge have been called upon to offer their expertise in service to the United States Supreme Court. Lower courts have utilized the amicus for various special formal assignments, similar to those of a Master or Referee. Such functions include the handling of special problems dealing with juvenile delinquents -and the individuals are sometimes designated by the anglicized title, Friends of the Court, to distinguish this investiture from the less formalized amicus function.

Again, a court may call upon members of the bar (or more usually appropriate law officers) to act directly on behalf of the court itself. Here, in a sense, the old private relationship of the lawyer to the court is recreated; the friendship of the officer is most emphatically for the court. Thus in Universal Oil Products Co. v. Root Refrigerating Co., ${ }^{120}$ the amici had been designated to participate in an inquiry with regard to the possibility of fraud and bribery in the original court order. When dishonesty on the part of a judge was shown, the amici who had also been attorneys for affected parties, though not principal litigants, sought to obtain compensation which in effect would have been re-

120. 328 U.S. 575,581 (1946). 
imbursement for their employers. The Court rejected such a claim. The role precluded their basically participating in a dual capacity:

No doubt, a court that undertakes an investigation of fratud upon it may avail itself, as did the court below, of amici to represent the public interest in the administration of justice. But compensation is not the normal re. ward of those who offer such services. ... Here the amici also represented substantial private interests. Their clients were interested in vacating the Root Judgment though they would not subject themselves to the court's jurisdiction and the hazards of an adverse determination. While the amici formally served the court, they were in fact in the pay of private clients. Amici selected by the court to vindicate its honor ordinarily ought not to be in the service of those having private interests in the outcome. Certainly it is not consonant with that regard for fastidiousness which should govern a court of equity, to award fees and costs of amici curiae who have already been compensated by private clients so that these be reimbursed for what they voluntarily paid. ${ }^{\mathbf{1 2 1}}$

Thus while vindicating the right to appoint such amici, the Supreme Court asserted a special relationship between such amici and the court who designates them.

Indeed "friendship" at this point becomes a peculiar sort of advocacy. The amicus becomes the spokesman for court interests in a vital and active sense. This is well borne out in the recent cases involving desegregation. The Supreme Court's device of delegating to the district courts the implementation of its desegregation decision has thrust upon the district courts an unustual burden of decision and activity. ${ }^{122}$ Where defiance has occurred, the courts have been particularly dependent upon the activities of the executive and have acknowledged this dependency.

So in both the Little Rock, Arkansas, and the University of Mississippi integration crises the federal district court, on its own initiative, designated the United States Attorney General and the United States Attorney as amici and specifically instructed its designated amici to carry out activities on behalf of the court. On September 9, 1957, in order to enforce its prior determinations ${ }^{12}$ the district court in Arkansas invited the Attorney General of the United States and the United States Attorney to

come into the case as [amici] curiae and to commence injunction proceedings against the Governor and his subordinates "to prevent the existing interferences with and obstructions to the carrying out of the orders heretofore entered by this Court in this case."124

On appeal to the Court of Appeals for the Eighth Circuit, the case was styled Faubus v. United States (amicus curiae). ${ }^{125}$ Among other claims, the attorneys for Governor Faubus argued that the United States had no standing to file such a petition for injunctive relief and that the court had erred in giving

121. Id. at $580-81$.

122. See Peltason, Fifty-Eight Lonely Men (1961).

123. Aaron v. Cooper, 156 F. Supp. 220 (E.D. Ark. 1957).

124. Aaron v. Cooper, 163 F. Supp. 13, 16 (E.D. Ark. 1958).

125. 254 F.2d 797 (8th Cir. 1958). 
the United States such powers. The court of appeals, however, found that this was in accordance with past procedure and that it was "proper for the court to do all that reasonably and lawfully could be done to protect and effectuate its orders and judgments." The district court had acted properly in asking the law officers of the United States to act on its behalf for it "could not with propriety employ private counsel to do the necessary investigative and legal work. It has, we think, always in the past been customary for a federal district court to call upon the law officers of the United States for aid and advice in comparable situations."126

There was no need to go into the legal theory too thoroughly, the court of appeals pointed out, inasmuch as the plaintiffs in the Aaron case were still real parties in interest and had joined the government in requesting this injunction. Nonetheless, the court of appeals emphatically upheld the authority both of the court and its amici:

In our opinion the status of the attorney general and the United States attorney was something more than that of mere amici curiae in private litigation. They were acting under the authority and direction of the court to take such action as was necessary to prevent its orders and judgments from being frustrated and to represent the public interest in the due administration of justice. ${ }^{12 \tau}$

Similarly, when it became obvious that the State of Mississippi was engaged on a course of defiance of the court orders in Meredith 2. Fair, ${ }^{128}$ the United States was designated as amicus curiae on September 18, 1962, by the Court of Appeals for the Fifth Circuit. It was authorized to appear before the court of appeals and the District Court for the Southern District of Mississippi

with the right to submit pleadings, evidence, arguments and briefs and to initiate such further proceedings, including proceedings, for injunctive relief and proceedings for contempt of court, as may be appropriate in order to maintain and preserve the due administration of justice and the integrity of the judicial processes of the United States. ${ }^{129}$

Two days later the amicus curiae asked for an injunction to prevent enforcement of a bill signed that very day by the governor which would have prevented Meredith from enrolling; the sheriff was also enjoined from proceeding on a rather weak perjury charge in connection with a previous voting enrollment by Meredith. ${ }^{130}$ On federal initiative a temporary restraining order was also issued by the court of appeals on September 25 enjoining the State of Mississippi, the governor, and numerous officials from interfering with Meredith's enrollment, as well as enjoining numerous legal steps leading toward this end, including the filing of actions in the state courts. ${ }^{131}$ With the governor's refusal,

126. Id. at 805 .

127. Ibid. Also joined as appellants but filing no briefs were Cooper, et al. of the Little Rock School Board.

128. 7 RACE ReL. L. Rep. 748 (1962). For background of the case, see Areredith v. Fair, 199 F. Supp. 754 (S.D. Miss. 1961).

129. 7 RACE REL. L. REP. 749 (1962).

130. Id. at $752-53$ (issuance of injunction).

131. Id. at 756-57. 
a show cause order went out to the governor and lieutenant governor and the contempt citation of September 28 was issued. The governor was convicted of civil contempt after evidence "on behalf of the United States and of the appellant,"132 while the lieutenant governor, on the 29th, was found gutily upon presentation only of "evidence on behalf of the United States." Ins In both instances the civil contempt was of the September 25 order which had been isstued upon the application of the amicus curiae.

The partial compliance of the governor with the orders of the court subsequently eliminated the need for civil contempt. However, in December, acting under orders from the court, the amicus curiae moved to have the governor found in criminal contempt because of his continuous criticism of the processes of integration and his consequent failure to purge himself of contempt. Not the least paradoxical aspect of the affair is the hiring of private counsel to represent the United States and the Attorney General. ${ }^{134}$ The judgment of the Department of Justice was that its staff had been too involved in the proceedings in their executive capacities to be the best possible vindicators of the court's honor.

Thus, even the closest possible relationship of friendship to the court-acting directly for it-has evolved into an active advocacy of the most demanding and consuming nature. This most fervent friendship for the court involves the taking on of the court as a special sort of client, one whose claims are of an even higher and purer partisanship.

\section{Conclusions}

The amicus curiae brief represents a prime example of a legal institution evolving and developing while maintaining superficial identity with the past. It has been a catch-all device for dealing with some of the diffictuties presented by the common law system of adversary proceeding. In the United States, in particular, it has allowed representation of governmental and other complex interests generated by the legal involutions of federalism. In addition, the United States Supreme Court has helped foster its development as a velicle for broad representation of interests, particularly in disputes where political ramifications are wider than a narrow view of common law litigation might indicate. Groups inherently weak in the political arenas or unequally endowed with resources of wealth or skills have quite naturally been the leaders in the use of the brief. The growth of the regulatory process and the welfare state lave played a significant role in fostering group organization and an awareness of policy determination by the judiciary.

On occasion, the amicus curiae has been an agent of the court acting as champion of the court's point of view, vigorously pursuing and defending a legal position at the request of the bench itself. In the main, however,

132. Id. at 761 (civil contempt conviction of Governor Barnett). Jr.).

133. Id. at 762 (civil contempt conviction of Lieutenant Governor Paul B. Jolinson,

134. Wall Street Journal, Dec. 24, 1962, p. 5, cols. 2-3. Mr. Leon Jaworski of the Texas Bar was hired to represent the United States. 
the amicus curiae has been a means of fostering partisan third party involvement through the encouragement of group representation by a self-conscious bench. The judges have sought to gain information from political groups as well as to give them a feeling of participation in the process of decision. Access to the legal process on the part of such organizations is a logical extension of realistic awareness of law as a process of social choice and policy making. Even criticism of the amicus curiae brief as "political propaganda," court embarrassment at such criticism, and changes in the rules which have hampered such briefs in the short run have not seriously stemmed the growing reliance upon it. 


\section{THE YALE LAW JOURNAL}

\begin{tabular}{lll}
\hline Volume 72 & MARCH 1963 & Numuer 4 \\
\hline
\end{tabular}

Arasand Derfier

JoHN HART ELY

JoEL JAY Finer

Robert M. Shepard

Note \& Comment

Editors

Barbara A. Babcock

ROBERT A. BuRT

Edward R. Cohe

RoBert E. CoOper

Theodore B. Donson

Stephen R. Fiezd

ASHLEY L. FORD

JosEPH W. Get.B

\author{
Lee A. Albert \\ Editor-in-Chief
}

Sangwoo AmN

Managing Editor

Paul Grossman

Allen I. Isaacson

ALAN D. JacoBson

HowARD J. KasLow

ANTHONY S. KOLKER

JoHN A. KosKINEN

Martin Levine

JOHN J. MCATEE, JR.

ARTaUR A. MUNISTERI

Marte McMahon

Business Secretary
Edgar S. Cains

Bruce E. Fritch

Article \& Book

Review Editors

Alan R. Novak

Topics Editor

JARIES J. MURRAY

Robert E. PuAY

Rodert B. Scanerden

Peter L. Strauss

ROGER W. TOMPKINS

Steven M. UaIN

EzLiotr J. Werss

WARREN G. WICKersHAM

\section{CONTRIBUTORS TO THIS ISSUE}

Wildiam O. Douglas. B.A. 1920, Whitman College; LL.B. 1925, Columbia University.

Thurman W. Arnold. B.A. 1911, Princeton University ; LL.B. 1914, Harvard University; M.A. 1931, Yale University ; LL.D. 1943, University of Wyoming.

Fleming Janes, JR. B.A. 1925, LL.B. 1928, Yale University.

Grant Gilmore. B.A. 1931, Ph.D. 1936, LL.B. 1942, Yale University.

Hugo L. BLACK, JR. B.A. 1949, University of Alabama; LL.B. 1952, Yale University.

Samuel Krislov. B.A. 1951, M.A. 1952, New York University ; Ph.D. 1955, Princeton University.

Marvin E. Frankez. B.A. 1943, Queens College, New York; LL.B. 1948, Columbia University.

Jerome A. Cohen. B.A. 1951, LL.B. 1955, Yale University.

Herdsan Frnkelstern. B.A. 1923, Clark University; LL.B. 1927, Yale University. 